\title{
REVITALISASI PENGGUNAAN OBAT GENERIK
}

\author{
Nanang Yunarto* \\ Badan Penelitian dan Pengembangan Kesehatan Kementerian Kesehatan RI
}

\begin{abstract}
Abstrak
Pemerintah melalui Kementerian Kesehatan sangat serius ingin merevitalisasi penggunaan obat generik dengan mengeluarkan kebijakan yang tertuang dalam Peraturan Menteri Kesehatan Nomor HK. 02.02/Menkes/068/1/2010 tentang kewajiban menggunakan obat generik di fasilitas pelayanan kesehatan pemerintah. Untuk memaksimalkan penggunaan obat generik, sangat diperlukan peningkatan pemahaman dan kepercayaan masyarakat bahwa obat generik memiliki kualitas, keamanan dan efektivitas yang sama dengan obat bermerek. Selain itu, dengan adanya banyak penelitian dan kajian tentang obat generik akan meningkatkan pengetahuan, sehingga tenaga kesehatan terutama dokter tidak ragu untuk meresepkan obat generik. Mutu dijadikan dasar acuan untuk menetapkan kebenaran khasiat (eficacy) dan keamanan (safety). Untuk produk-produk tertentu availabilitas dapat ditunjukkan secara in vitro. Studi disolusi obat memberikan indikasi yang sama dengan bioavailabilitas obat. Idealnya disolusi obat in vitro berkorelasi bioavailabilitas (ketersediaan hayati) invivo. Dari hasil penilitian uji disolusi obat generik tablet Amoksisilina 500 mg, tablet Isosorbit Dinitrat 5 mg dan kapsul Omeprazol dibandingkan dengan obat bermerek menunjukkan obat generik tidak kalah dengan obat bermerek, bahkan hasil uji disolusi obat generik relatif lebih baik.
\end{abstract}

Kata kunci : revitalisasi, obat generik, uji disolusi

\begin{abstract}
The government through the Ministry of Health is very serious about revitalizing the use of generic drugs by issuing a policy that stipulated in the Regulation of the Minister of Health No. HK. 02.02/Menkes/068/1/2010 about duty to use generic drugs in government health care facilities. To maximize the use of generic drugs, it is very important to improve understanding and trust of society that generic drugs have the quality, safety and effectiveness are similar to branded drugs. Besides that, there is a lot of research and the study of generic drugs will increase the knowledge, so that health professionals, especially doctors do not hesitate to prescribe generic drugs. Quality used as a basis of reference to establish the truth of the eficacy and safety. For availability of certain products can be demonstrated in vitro. Studies of drug dissolution gave the same indication with drug bioavailability. Ideally, in vitro drug dissolution correlates bioavailability in vivo. From the research results of dissolution test generic drugs Amoxiciline $500 \mathrm{mg}$ tablets, Isosorbit Dinitrat $5 \mathrm{mg}$ tablets and Omeprazole capsules compared to branded drugs show no less generic drugs than branded drugs, dissolution test results even better generic drugs
\end{abstract}

Keywords : revitalizing, generic drugs, dissolution test 


\section{Pendahuluan}

Pada tahun 2010 ini, pemerintah melalui Kementerian Kesehatan sangat serius ingin merevitalisasi penggunaan obat generik dengan mengeluarkan kebijakan yang tertuang dalam Peraturan Menteri Kesehatan Nomor HK. 02.02/Menkes/068/ 1/2010 tentang kewajiban menggunakan obat generik di fasilitas pelayanan kesehatan pemerintah. Penggunaan obat generik akan sangat menghemat biaya penanganan penyakit. Selama ini, biaya obat diatas 50 $\%$ dari total biaya pengobatan yang seharusnya dapat ditekan lebih rendah. Sebanyak 453 obat generik yang harga eceran tertingginya dikontrol pemerintah sudah dapat mengatasi sekitar $70 \%$ penyakit yang ada.

Untuk memaksimalkan penggunaan obat generik, sangat diperlukan peningkatan pemahaman dan kepercayaan masyarakat bahwa obat generik memiliki kualitas, keamanan dan efektivitas yang sama dengan obat bermerek. Selain itu, dengan adanya banyak penelitian dan kajian tentang obat generik akan meningkatkan pengetahuan, sehingga tenaga kesehatan terutama dokter tidak ragu untuk meresepkan obat generik.

Telaahan ini akan membahas tentang obat generik, kualitas obat generik melalui studi hasil uji disolusi beberapa obat generik dibandingkan dengan obat bermerek agar dapat menjawab keraguan kita terhadap obat generik sehingga penggunaannya di fasilitas pelayanan kesehatan dapat ditingkatkan.

\section{Sekilas tentang obat generik}

Obat merupakan unsur yang sangat penting dalam upaya penyelenggaraan kesehatan. Sebagian besar intervensi medik menggunakan obat, oleh karena itu obat tersedia pada saat diperlukan dalam jenis dan jumlah yang cukup, berkhasiat nyata dan berkualitas baik. Saat ini banyak sekali beredar berbagai macam jenis obat baik itu produk generik maupun produk dagang, pada umumnya konsumen lebih suka mengkonsumsi produk bermerek/produk dagang dibanding produk generik, hal ini disebabkan adanya anggapan bahwa obat generik mempunyai mutu lebih rendah daripada produk yang bermerek dagang. Dokter juga seringkali memberikan resep non generik kepada pasien sebagai pilihan untuk pengobatan, padahal harga produk bermerek biasanya lebih mahal dari obat generik, sehingga bagi pasien yang tidak mampu sering membeli setengah obat resep dokter. Hal ini sangat berbahaya, terutama bila obat tersebut adalah suatu antibiotik, jika diminum tidak sampai habis dapat mengakibatkan mikroba dalam tubuh pasien menjadi kebal/resisten terhadap antibiotik tersebut.

Obat Generik menurut Permenkes No. 089/Menkes/Per/1/1989 adalah obat dengan nama resmi yang ditetapkan dalam Farmakope Indonesia untuk zat berkhasiat yang dikandungnya, produk obat generiknya disebut Obat Generik Berlogo (OGB), yaitu obat jadi dengan nama generik yang diedarkan dengan mencantumkan logo khusus pada penandaannya. Obat bermerek dagang (branded drug) adalah nama sediaan obat yang diberikan oleh pabriknya dan terdaftar di Kementerian Kesehatan maupun Badan Pengawasan Obat suatu negara, disebut juga sebagai merek terdaftar. Satu nama generik dapat diproduksi berbagai macam sediaan obat dengan nama dagang yang berlainan.

Produksi obat generik merupakan salah satu upaya penyediaan obat yang bermutu dengan harga yang terjangkau oleh seluruh lapisan masyarakat. Obat generik umumnya memiliki harga yang lebih murah, beberapa faktor yang menyebabkan hal tersebut adalah

a) Dalam harga obat nama dagang, terdapat komponen biaya promosi yang cukup tinggi mencapai sekitar 
50\% dari HET (Harga Eceran Tertinggi) baik melalui iklan untuk obat bebas/obat bebas terbatas dan melalui detailer untuk obat keras, sedangkan obat generik tidak dipromosikan secara khusus.

b) Harga obat dengan nama dagang biasanya ditetapkan berdasarkan mekanisme pasar dengan memperhitungkan harga kompetitor, sedangkan harga obat generik lebih didasarkan pada biaya kalkulasi nyata.

c) Harga obat dengan nama dagang biasanya mengikuti harga inovator dari obat yang sama, sedang obat generik di Indonesia ditetapkan oleh pemerintah melalui Kementerian Kesehatan

Di Indonesia, pembuatan obat generik maupun obat bermerek oleh Badan Pengawasan Obat dan Makanan (BPOM) diatur dalam Pedoman Cara Pembuatan Obat yang Baik (CPOB). Persyaratan registrasi obat sangat ketat, BPOM baru akan menyetujui obat generik mendapatkan nomor registrasi dan beredar jika sudah memenuhi syarat seperti : produsen memiliki sertifikat CPOB dari BPOM, obat tersebut sudah tervalidasi baik proses, maupun analisanya, serta mesin dan peralatan yang digunakan untuk produksi dan analisa sudah terkualifikasi. Selain itu produk obat juga harus memenuhi seluruh standar yang digunakan dalam identitas, kekuatan, kualitas dan kemurnian Bahkan untuk obat generik me-too pertama ada persyaratan bioavailabilitas dan bioekivalensi dengan obat paten yang habis masa edarnya. Mutu suatu sediaan obat dapat ditinjau dari berbagai aspek antara lain aspek teknologi yang meliputi stabilitas fisik dan kimia dimana sediaan obat (tablet, kapsul dan sediaan lainnya) harus memenuhi kriteria yang dipersyaratkan Farmakope, selain itu mutu obat juga ditinjau dari bioavailabilitas obat
(Ansel et al, 2005). Mutu dijadikan dasar acuan untuk menetapkan kebenaran khasiat (eficacy) dan keamanan (safety). Untuk produk-produk tertentu availabilitas dapat ditunjukkan secara in vitro. Studi disolusi obat memberikan indikasi yang sama dengan bioavailabilitas obat. Idealnya disolusi obat in vitro berkorelasi bioavailabilitas (ketersediaan hayati) invivo (Shargel et al, 2009).

\section{Disolusi}

Pelarutan merupakan proses dimana suatu bahan kimia atau obat menjadi terlarut dalam suatu pelarut. Dalam sistem biologi pelarutan obat dalam media"aqueous" merupakan suatu bagian penting sebelum kondisi sistemik. Laju pelarutan obat dengan kelarutan dalam air sangat kecil dari bentuk sediaan padat yang utuh atau terdisintegrasi dalam saluran cerna sering mengendalikan laju absorbsi sistemik obat (Sinko, 2009).

Disolusi merupakan tahapan yang membatasi atau tahap yang mengontrol laju bioabsorbsi obat-obat yang mempunyai kelarutan rendah, karena tahapan ini seringkali merupakan tahapan yang paling lambat dari berbagai tahapan yang adadalam pelepasan obat dari bentuk sediaannya dan perjalanannya ke dalam sirkulasi sistemik (Anonim, 2003).

Disolusi juga merupakan salah satu kontrol kualitas yang sangat penting untuk sediaan farmasi. Disolusi merupakan suatu kontrol kualitas yang dapat digunakan untuk memprediksi bioavailabilitas, dan dalam beberapa kasus dapat sebagai pengganti uji klinik untuk menilai bioekivalen. Sifat disolusi suatu obat berhubungan langsung dengan aktivitas farmakologinya. Hubungan kecepatan disolusi in vitro dan bioavailabilitasnya dirumuskan dalam bentuk invitroinvivo-correlation (Sulaiman dkk, 2009). 
Tabel 1. Kadar Hasil Uji Disolusi Tablet Amoksisilina 500 mg (Harianto dkk, 2006).

\begin{tabular}{|l|l|c|}
\hline No. & \multicolumn{1}{|c|}{ Obat } & $\begin{array}{c}\text { Kadar Hasil } \\
\text { Uji Disolusi (\%) }\end{array}$ \\
\hline 1. & Generik I & $\mathbf{1 0 5 , 7 4}$ \\
\hline 2. & Generik II & 104,98 \\
\hline 3. & Generik III & 105,65 \\
\hline 4. & Benmerek I & 97,54 \\
\hline 5. & Bermerek II & 96,49 \\
\hline 6. & Bermerek III & 94.20 \\
\hline
\end{tabular}

Tabel 2. Kadar Hasil Uji Disolusi Tablet Isosorbit Dinitrat 5 mg (Alegantina dkk, 2008).

\begin{tabular}{|l|l|c|}
\hline No. & \multicolumn{1}{|c|}{ Obat } & $\begin{array}{c}\text { Kadar Hasil } \\
\text { Uji Disolusi (\%) }\end{array}$ \\
\hline 1. & Generik I & 102,42 \\
\hline 2. & Generik II & 99,86 \\
\hline 3. & Bermerek (Inovator) & 99,73 \\
\hline
\end{tabular}

Tabel 3. Kadar Hasil Uji Disolusi Kapsul Omeprazol (Isnawati dkk, 2007).

\begin{tabular}{|l|l|c|c|}
\hline \multirow{2}{*}{ No. } & \multicolumn{2}{|c|}{ Obat } & \multicolumn{2}{c|}{ Kadar Hasil Uji Disolusi (\%) } \\
\cline { 3 - 4 } & & Tahap Asam & Tahap Basa \\
\hline 1. & Generik & 95,38 & 107,61 \\
\hline 2. & Bermerek I (Inovator) & 95,94 & 103,59 \\
\hline 3. & Bermerek II (me too) & 93,72 & 85,56 \\
\hline
\end{tabular}

\section{Beberapa Hasil Uji Disolusi Obat Generik dan Obat Bermerek}

Beberapa penelitian mengenai pharmaceutical availability telah dilakukan dengan tablet dan kapsul sebagai bentuk sediaan yang paling umum. Setelah ditelan tablet/kapsul akan pecah di lambung dan menjadi granul kecil, yang terdiri dari zat aktif tercampur zat-zat pembantu. Setelah granul-granul ini pecah, zat aktif dibebaskan. Bila daya larutnya cukup besar, zat aktif tersebut akan melarut dalam cairan lambung/usus, tergantung dimana obat pada saat itu berada. Setelah melarut, obat tersedia dan proses resorpsi oleh usus dapat dimulai. Peristiwa inilah yang disebut pharmaceutical availability (Sulihtyowati, 2001).

Tabel 1, Tabel 2 dan Tabel 3 menunjukkan beberapa hasil penelitian tentang uji disolusi obat generik dibandingkan dengan obat bermerek.

\section{Pembahasan}

Dari hasil penilitian uji disolusi obat generik tablet Amoksisilina 500 mg, tablet Isosorbit Dinitrat $5 \mathrm{mg}$ dan kapsul 
Omeprazol dibandingkan dengan obat bermerek menunjukkan obat generik tidak kalah dengan obat bermerek, bahkan hasil uji disolusi obat generik relatif lebih baik.

Kelangkaan informasi obat generik dapat menjadi penyebab utama timbulnya berbagai masalah, terutama dalam hal tanggapan masyarakat dan praktisi medik terhadap nilai kepentingan dan kebutuhan obat generik. Oleh karena harga obat generik murah, masyarakat menganggap kalau obat generik tidak berkhasiat, tidak sekhasiat obat-obat paten maupun obat bemerek. Informasi obat generik saat ini sangat diperlukan sehingga perlu diperluas dan ditingkatkan dengan maksud untuk lebih membuka dan meningkatkan kesadaran dan pemahaman masyarakat tentang obat generik.

Anggaran penelitian dan promosi obat generik seharusnya ditingkatkan sehingga masyarakat mengetahui keunggulan dan kelebihannya. Bagi orang awam, diberi obat yang murah barangkali tidak masalah dan bisa menerima. Namun, kalangan intelektual dan praktisi medik memerlukan evidence (fakta, bukti) dan komparasi dengan obat paten. Artinya, diperlukan juga penelitian sehingga diperlukan dukungan dari pemerintah untuk penelitian tersebut. Penelitian dasar obat harus terus dikembangkan, sehingga Indonesia bisa seperti Cina dan India yang bisa maju industri obatnya. Hingga sekarang Indonesia kurang mengembangkan industri hulu di bidang obat. Sehingga hampir semua bahan baku obat diimpor yang tentu saja harga obat menjadi mahal. Padahal, kalau mau industri farmasi bisa membuat industri hulu di bidang obat karena bahan bakunya sebenarnya tersedia di Indonesia. Industri farmasi seharusnya lebih kreatif dan tidak hanya mengutamakan aspek bisnis semata.

Menteri Kesehatan sudah mengeluarkan aturan yang mewajibkan dokter menulis resep obat generik di fasilitas pelayanan kesehatan pemerintah bagi semua pasien sesuai indikasi medis dan akan memberi sanksi hukum bagi yang melanggar yang tertuang dalam SK MenKes Nomor 85/ 1995 tentang Penggunaan Obat Generik, kemudian ditegaskan kembali dalam kebijakan terbaru Peraturan Menteri Kesehatan Nomor HK. 02.02/Menkes/068/ 1/2010. Kemudian apoteker diberi kewenangan untuk mengganti obat bemerek dengan obat generik yang sama zat aktifnya atas persetujuan dokter dan/atau pasien. Dengan demikian perlu kesadaran dan kerja sama yang sinergi antara pemerintah, produsen obat, dokter, apoteker dan praktisi medik lainnya dalam peningkatan penggunaan obat generik. Sehingga image masyarakat tentang obat generik menjadi berubah.

\section{Kesimpulan}

Dari hasil beberapa penelitian uji disolusi sudah dibuktikan bahwa obat generik tidak kalah dengan obat bermerek. Sekarang semua pilihan kembali pada kita sebagai konsumen dan tenaga kesehatan, apakah kita mau membeli khasiat atau mau membeli merek. Semoga program Kementerian Kesehatan untuk meningkatkan penggunaan obat generik dapat berjalan baik sehingga rakyat Indonesia dapat hidup lebih sehat dan lebih baik melalui penggunaan obat generik.

\section{Daftar Pustaka}

Alegantina, S., Lestari, P., Mutiatikum D., (2008), Penelitian Disolusi dan Penetapan Kadar Isosorbit Dinitrat Dalam Sediaan Generik dan Sediaan Inovator, http:// www.litbang.depkes.go.id/media

Anonim, 2003, The United States

Pharmacopeia 26, Washington,

DC, US Pharmacopeial

Convention Inc. 
Ansel, H.C., Popovich, N.G., Allen, L.E., 2005 Pharmaceutical Dosage Form and Delivery System, $8^{\text {th }}$ Edition, Baltimore, Lippincott Williams \& Wilkins

Harianto, Sabarijah, Fitri Transitawuri, (2006), Perbandingan Mutu dan Harga Tablet Amoksisilin $500 \mathrm{mg}$ Generik Dengan Non Generik Yang Beredar di Pasaran, Vol.3 Jakarta, Majalah Ilmu Kefarmasian

Isnawati, A., Lestrari, P., Uji Disolusi Kapsul Omeprazol Produksi Obat Generik Berlogo dan Produksi Nama Dagang, http:// www.isfinational.or.id/pt-isfipenerbitan/123/437

Shargel, L., Sauney, P.F., Mutnick, A.H, Swanson, L.N., (2009)

Comprehensive Pharmacy

Review, $7^{\text {th }}$ Edition, Baltimore, Lippincott Williams \& Wilkins

Sinko, P.J., 2005, Physical Pharmacy and Pharmaceutical Science, 6 Edition, Baltimore, Lippincott Williams \& Wilkins

Sulaiman, T.N., Kurniawan, D.W, (2009)

Tekonologi Sediaan Farmasi, Jogjakarta, Graha Ilmu

Sulihtyowati, S., 2001, Teknologi

Formulasi Sediaan Padat, Jogjakarta, Universitas Gadjah Mada, Jogjakarta 